\title{
Methanol/Water-based Buffered Preservative Solution
}

National Cancer Institute

\section{Source}

National Cancer Institute. Methano//Water-based Buffered Preservative Solution. NCI

Thesaurus. Code C113702.

A methanol-water solution for the preservation of cervical cells for automated Pap testing. 